\title{
Self-Assessment of Social and Family Loneliness in Elderly during COVID-19 Pandemic in Relation to Current Level and Type of Communication Intensity
}

\author{
Želimir Bertići, Mirjana Telebuh ${ }^{2}$ \\ ${ }^{1}$ Institute of Public Health of Bjelovar-Bilogora County, Bjelovar, Croatia \\ ${ }^{2}$ University of Applied Health Studies, Zagreb, Croatia
}

\begin{abstract}
A B S T R A C T
Due to the spread of coronavirus people throughout the world, many countries, Croatia included, have been forced to impose social distancing resulting in an increased number of people at risk of another public health problem - loneliness. Loneliness can be defined as the presence of negative emotions associated with the perceived social exclusion and is identified as one of the major issues of the aging population. There is a relatively small number of studies either dealing with the use of various communication methods, particularly information and communication technologies, by the elderly during the COVID-19 pandemic or determining potential benefits of such activities. The aim of this research was to determine the difference in self-assessment of social and family loneliness according to the means of communication used by the elderly during the COVID-19 pandemic. The research was conducted in March and April 2020 covering the period from the introduction of the epidemiological measures of social distancing and self-isolation until the relaxation of virusrelated restrictions in Croatia. The research included 107 subjects over the age of 65 living in their own homes in the Croatian city of Bjelovar. A Frequency of the Used Communication Methods Questionnaire was constructed for the purpose of this research. The Social and Emotional Loneliness Scale for Adults was used to determine the level of loneliness. The obtained results indicate that lower levels of social and family loneliness were shown by subjects who stated in their selfassessment a higher intensity level of communication during the COVID-19 pandemic, such as making telephone/mobile phone calls, using information technology (computers for video calls, social networks, etc.) and mobile chat applications (Viber, Skype, WhatsApp, etc.), as well as having face-to-face communication. Subjects who rarely or never communicated by using any means of the abovementioned communication showed higher levels of social and family loneliness. Results of this research suggest that using various communication methods, particularly modern communication technologies, have a positive effect on reducing the level of loneliness in the elderly. Teamwork of gerontologists, communication technologists and other experts who work with older population could introduce them to communication technology thus making them more satisfied and improving their quality of life.
\end{abstract}

Key words: loneliness, elderly, COVID-19, social loneliness, communication, communication technology

\section{Introduction}

In December 2019 a rapid increase of patients with pneumonia was registered in Wuhan, China, and COVID-19 disease caused by coronavirus (SARS-CoV-2) was recognised for the first time ${ }^{1}$. The disease spread to all the continents over several months and it has become a health, social and economic problem for the population of almost all the countries in the world. To prevent further spread of the virus among their population many countries introduced epidemiological measures. Some of the main measures that numerous countries in the world, including
Croatia, were forced to introduce were social self-isolation or distancing. Even though social distancing is an appropriate response to the current pandemic it is well-known that social isolation and loneliness have a negative effect on health ${ }^{2}$.

\section{Loneliness and the elderly}

Loneliness is a subjective, unpleasant, aversive, and stressful experience which occurs when an individual's social network becomes deficient in its quality or quantity ${ }^{3}$. Loneliness can be defined as presence of negative emotions related to the perceived social isolation ${ }^{4}$. Due to the 
spread of coronavirus we are obliged to live in stricter social isolation or social distancing which results in an increasing number of people at risk of another public health problem - loneliness.

Loneliness is recognised as one of the major problems of aging and at the same time it plays a significant role in the subjective feeling of life satisfaction ${ }^{4}$. The elderly population are most exposed to various factors contributing to negative changes in life and various levels of social isolation or loneliness ${ }^{5,6}$. Death of the spouse, siblings or friends, illness, retirement, disability, lower income, and increasing dependence on other people cause risk for a variety of negative life changes including the feeling of loneliness. Fewer friends, a change of life roles, and reduced activity in different areas of life by choice or imposed by the environment can cause social isolation and loneliness in the elderly ${ }^{7}$. A research conducted in January 2020 showed that $50 \%$ of baby boomers (born before the 1960s) feel lonely ${ }^{8}$. Loneliness is negatively correlated with happiness, self-esteem, and general satisfaction with life which often leads to various physical diseases that can have tragic consequences for older people ${ }^{9}$. People who feel disconnected from their family and community can develop depression, cardiovascular diseases, even decline of cognitive functions, all of which have a detrimental effect on the health of an individual ${ }^{2}$. The source of satisfaction and social support for the elderly comes from their community and emotional support of their children, relatives and friends all of which are currently disrupted due to the preventative measures of social distancing introduced to combat the coronavirus pandemic. The elderly enjoy spending time with people who they are close to knowing that they can rely on them should the need arise ${ }^{10,11}$. Family support functions as protection and has a positive effect since it helps the elderly to cope with widowhood, it reduces stress, neutralises negative influences, helps them adjust more successfully, and improve their health status, as well as the quality of life and social interactions ${ }^{12}$. Living alone does not mean being lonely as many people who live alone have an active and socially integrated lifestyle, but it has been noted that loneliness is more common among people who live alone ${ }^{4,6,13,14}$.

Even if coronavirus currently socially separating people, particularly the elderly, were not present, it seems that older people would have a high risk of developing health issues related to social isolation which can aggravate this public health problem. The elderly (65+) make about $20 \%$ of the total population of Europe and their number continues to increase $\mathrm{e}^{15,16}$. For this reason, research aimed at better understanding the problem of social isolation of the elderly and improving their health and quality of life is very important for the society.

\section{Information and communication technology, the elderly and loneliness}

The age limit of the people using information and communication technology is increasing including a growing number of people over 65 who use different communication devices, such as mobile phones, tablets, etc. ${ }^{15,16}$. A trend in developed countries of the European Union suggests that every other person over 65 uses information and communication technology ${ }^{16}$. Despite the growing number of the elderly using the Internet there are still significant differences among the countries of the EU. For example, $68-84 \%$ of the elderly in Scandinavian countries, Great Britain and the Netherlands use information and communication technology actively, while there are only $15 \%$ of older people in Croatia using it $^{16,17}$.

Information and communication technology can help the elderly because it enables them to maintain or improve their skills, connect with and keep in touch with members of their family and friends, get information and the news. According to research results older people who use information technology have better social resources, so it is not surprising that one of the most common reasons for using information technology is to communicate with family members and get social support ${ }^{18-20}$. Prevention of dementia is another benefit of using information technology besides having better social resources ${ }^{19,21}$. It has also been established that using information technology can improve memory in the old age, it has a positive effect on cognitive functioning ${ }^{17,22,23}$ and mental health ${ }^{24-27}$. A longitudinal study showed that using the Internet reduces the likelihood of developing depressive states in the elderly which was most evident among those who lived alone ${ }^{28}$. It indicates that the mechanism of using information technology reduces the occurrence of depressive states because the feeling of social isolation and loneliness diminishes ${ }^{28,29}$.

We have to agree to the fact that communication among people has changed. Traditional communication through letters is almost non-existent and one of the global communication phenomena which have expanded the most in the last ten years are social networks. We live in a new digital age with less face-to-face communication and this change is also affecting older population. However, there are some problems, mostly due to their ignorance of technology, but the availability of training is slowly solving these problems. Although use of information technology by younger age groups is often associated with negative consequences like addiction to the Internet ${ }^{30}$, in an advanced age the Internet can become a suitable platform for communication and a way of gaining independence. It particularly applies to older people separated from their family members and friends and those who are less mobile. Information and communication technology is no longer a thing of the future, but of the present and it is necessary to keep up with the changes it offers.

\section{Aim and Hypotheses}

The aim of this research was to determine a difference in self-assessment of social and family loneliness in the elderly according to the means of communication 
used during the pandemic. It is, therefore, an applicative research with a specific goal of social intervention based on scientifically collected and processed data, aimed at a better position, status and satisfaction of the elderly.

The following hypothesis results from previously presented empirical knowledge and theoretical concepts: There is a difference in self-assessment of social and family loneliness in the elderly in relation to the current level and/or types of communication intensity during the COVID-19 pandemic. The basic hypothesis has two subhypotheses: in relation to the current level of communication (H1) and in relation to the type of communication intensity (H2).

\section{Methodology}

\section{Sample and data collection}

The survey was conducted in March and April 2020, from the introduction of the epidemiological measures of social distancing and self-isolation until the relaxation of virus-related restrictions in Croatia ${ }^{31}$. The research included 107 subjects over the age of 65 living in their own homes in Bjelovar. It is important to note that only older people living at home with a spouse or a partner and those living alone were included in the research. The elderly with severe cognitive, psychological or physical disorders, such as dementia, mental illnesses, or complete immobility, were not included in the research.

The subjects were chosen among the members of the Bjelovar Old Age Pensioners Association, but only those living in their households alone or with a partner and not the elderly who lived in extended families or nursing homes at the time of the recommended social isolation. The choice of subjects (living at home) was based on greater need to use the researched types of communication (face-to-face, telephone and information technologies). Due to the obligation of adhering to the epidemiological measures of social distancing the questionnaires used in this research were sent by mail with a detailed explanation of the purpose and aim of the research. The subjects received a franked mail envelope and were asked to return it to the authors' addresses after signing the consent and filling in the attached questionnaire. 48 subjects were sent the questionnaire by email upon their request. A total of 118 questionnaires were sent, 70 $(59.2 \%)$ of which by mail and $48(48.8 \%)$ by email. We received 107 filled in questionnaires $(90.95 \%)$, of which 101 questionnaires (94.42\%) were correctly filled in and six questionnaires $(5.85 \%)$ were not. The six incorrectly filled in questionnaires were excluded from the analysis because of the incomplete information provided by the subjects. The questionnaire included contact information (telephone numbers and email addresses of the authors of the research) for the respondents to use in case of uncertainties about filling in the questionnaire. 8 subjects requested assistance in filling the questionnaire by email and 19 by telephone.

\section{Description of the instruments}

The first part of the questionnaire consisted of four questions related to the sociodemographic characteristics of the subjects: gender, age, way of life (alone, with a spouse or a partner), marital status (married/common law marriage, single, divorced, widowed) and level of education (no education, primary school, secondary school, higher education, faculty, master's or doctoral degree).

The second part of the questionnaire related to the frequency of types of communication used during the COVID-19 pandemic. It consisted of four statements about the frequency of using the following means of communication: telephone/mobile phone calls, information technology (computer for video calls, social networks, etc.), face-toface, and mobile phone chat applications (Viber, Skype, WhatsApp, etc.). The statements were evaluated in the questionnaire according to the 4 point Likert Scale (1 never, 2 - very rarely, 3 - occasionally, 4 - constantly). Results in the questionnaire range between 4 and 16 where higher results indicate a higher frequency of using certain means of communication. For the purpose of this research the results are divided into two values in relation to the central tendency (median), lower under and higher above the central tendency. The results are also presented for each statement separately (by the four levels the respondents used in their answers: never, very rarely, occasionally, and constantly) which provided another insight into the intensity level of each communication method.

The third part of the questionnaire consisted of the standardized Social and Emotional Loneliness Scale for Adults (SELSA) ${ }^{33}$ translated into Croatian as Skala socijalne $i$ emocionalne usamljenost ${ }^{32}$. The scale consisted of three subscales separately examining social loneliness (13 statements), family loneliness (11 statements), and loneliness in love (12 statements). A 7-point Liker Scale was used for all the items. A higher score in one of the subscales indicated a higher level of loneliness in that particular domain. The score on the scale ranged between 13 and 91 on the subscale of social loneliness, between 11 and 77 on the subscale of family loneliness, and between 12 and 84 on the scale of loneliness in love. In the study on a sample of Croatian students the Social and Emotional Loneliness Scale for Adults proved to be highly reliable (the Cronbach Alpha coefficients for the subscales were: 0.89 for social loneliness, 0.85 for family loneliness, and 0.91 for loneliness in love) ${ }^{32}$. The above subscales in this research were also satisfactorily reliable (the Cronbach Alpha coefficients for the subscales were: 0.90 for social loneliness, 0.89 for loneliness in love, and 0.88 for family loneliness).

\section{Sociodemographic characteristics of the subjects}

The research included 101 elderly subjects, 56.4\% of whom were women and $43.6 \%$ men. The youngest respondent was 66 and the oldest 83 years old. The average age of the respondents was $71(\mathrm{SD}=4.23)$, which was also the most common age in the sample. $64(63.36 \%)$ subjects lived with their spouse or partner while 37 (36.64\%) subjects lived alone. 
Most respondents were widowed (43.3\%), 41.2\% were married or lived in a common law marriage, $13.1 \%$ were divorced, and the fewest subjects (2.4\%) were never married. Considered from the gender point of view more women in the sample (49.84\%) were widowed than men (37.17\%), whereas more men (48.89\%) were married than women (33.12\%) as shown in Table 1. Such discrepancy between men and women is justified by the fact that women live longer than men and have more nonfatal chronic diseases ${ }^{34,35}$. There are more women than men in the older population and this imbalance increases with age $^{36-38}$.

TABLE 1

MARITAL STATUS OF PARTICIPANTS INVOLVED IN THE SURVEY

\begin{tabular}{llccc}
\hline \multirow{2}{*}{ Marital status } & \multirow{2}{*}{$(101)$} & \multicolumn{2}{c}{ Gender } \\
\cline { 3 - 4 } & & $\mathrm{M}(43)$ & $\mathrm{F} \mathrm{(58)}$ \\
\hline 1 & $\begin{array}{l}\text { Married/common law } \\
\text { marriage }\end{array}$ & $41.2 \%$ & $48.89 \%$ & $33.12 \%$ \\
2 & Single (never married) & $2.4 \%$ & $2.33 \%$ & $3.41 \%$ \\
3 & Divorced & $13.1 \%$ & $11.61 \%$ & $13.63 \%$ \\
4 & Widowed & $43.3 \%$ & $37.17 \%$ & $49.84 \%$ \\
\hline
\end{tabular}

\section{Data processing methods}

The research data was processed by the IBM SPSS Statistics V24.0 software. The sample was divided in accordance with the hypotheses we were testing and a difference test was carried out. The Kolmogorov-Smirnov Test was used to determine distribution normality for more than 50 distributions and the Shapiro-Wilk Test for fewer than 50 distributions. The measured distribution of results was not normal $(\mathrm{p}<0.05)$. In order to avoid wrong conclusions the differences among groups were tested by nonparametric procedures: the Mann-Whitney Test to establish significant differences between two categories, the Kruskal-Wallis Test to determine differences among more than two categories, and the post hoc Mann-Whitney Analysis Test to identify the categories in question. A difference equal to or lower than $5 \%$ of risk $(p \leq 0.05)$ was considered as a significance level.

\section{Results}

The following analyses were performed on a sample of 101 elderly people, which we divided into two categories (in relation to the current level of communication and in relation to the type of communication intensity) according to the goal and the research hypothesis we were testing. Nonparametric procedures were carried out to test the differences among groups and a difference equal to or less than $5 \%$ of the risk $(\mathrm{p} \leq 0.05)$ was considered as a level of significance.
Difference in self-assessment of social and family loneliness in relation to the current level of communication

It is evident from Table 2 that there is a significant difference between the categories of subjects with regard to the current level of communication on the social loneliness subscale $(p=0.03)$ and the family loneliness subscale $(p=0.00)$ of the Social and Emotional Loneliness Scale for Adults. Subjects who stated in the self-assessment a "higher level" of communication in the frequency of communication questionnaire had statistically significantly lower results on the social and family loneliness subscales in comparison with the subjects who stated a "lower level" of communication. The obtained results demonstrate that the respondents with self-assessed "higher level" of communication during the COVID-19 pandemic showed a lower social and family loneliness in comparison with the respondents with self-assessed lower level of communication.

\section{TABLE 2}

MANN-WHITNEY TEST OF DIFFERENCES IN SOCIAL AND FAMILY LONELINESS SUBSCALES BY THE CURRENT LEVEL OF COMMUNICATION

\begin{tabular}{lcccc}
\hline Subscales & $\begin{array}{c}\text { Current communi- } \\
\text { cation level }\end{array}$ & $\mathrm{N}$ & $\begin{array}{c}\text { mean } \\
\text { rank }\end{array}$ & $\mathrm{p}$ \\
\hline Social loneliness & lower & 45 & 20.31 & 0.03 \\
& higher & 56 & 51.67 & \\
Family loneliness & lower & 45 & 18.86 & 0.00 \\
& higher & 56 & 59.57 & \\
\hline
\end{tabular}

Difference in self-assessment of social loneliness and family loneliness with regard to the type of communication intensity

It is evident from Table 3 that certain categories of respondents differ significantly on the social loneliness subscale $(\mathrm{p}=0.04)$ and on the family loneliness scale $(p=0.02)$ of the Social and Emotional Loneliness Scale for Adults with regard to the intensity of communication by telephone/mobile phone.

TABLE 3

KRUSKAL-WALLIS COMPARISON TEST OF SOCIAL AND FAMILY LONELINESS BY COMMUNICATION INTENSITY ON TELEPHONE/MOBILE PHONE

\begin{tabular}{lcc}
\hline Subscales & Chi-Square & $\mathrm{p}$ \\
\hline Social loneliness & 24.356 & 0.04 \\
Family loneliness & 42.431 & 0.02 \\
\hline
\end{tabular}

A post hoc Mann-Whitney Test Analysis was used to identify communication intensity categories in telephone/ mobile phone conversations. Table 4 shows only the results in which a statistically significant difference $(p \leq 0.05)$ 
between pairs within subscales was established. Subjects who claimed in the self-assessment that they "constantly" or "occasionally" communicated by telephone/mobile phone achieved statistically significantly lower results on the social loneliness subscale in comparison with the subjects who claimed in the self-assessment that they "never" communicated and those who communicated "very rarely". Similarly, respondents who self-assessed that they "constantly" or "occasionally" communicated by telephone/ mobile phone achieved statistically significantly lower results on the family loneliness subscale in comparison with the respondents who claimed that they "never" communicated and those who communicated "very rarely". The obtained results showed that subject who stated in the self-assessment that they "constantly" or "occasionally" communicated during the COVID-19 pandemic by telephone/mobile phone demonstrate lower levels of social and family loneliness on the Social and Emotional Loneliness Scale for Adults unlike the subject who never or very rarely communicated by telephone/mobile phone.

\section{TABLE 4}

MANN-WHITNEY TEST OF DIFFERENCES IN SOCIAL AND FAMILY LONELINESS BY THE INTENSITY OF COMMUNICATION ON TELEPHONE/MOBILE PHONE

\begin{tabular}{|c|c|c|c|c|}
\hline Subscales & $\begin{array}{l}\text { Intensity of } \\
\text { communication } \\
\text { by telephone/ } \\
\text { mobile phone }\end{array}$ & $\mathrm{N}$ & $\begin{array}{l}\text { mean } \\
\text { rank }\end{array}$ & $\mathrm{p}$ \\
\hline \multirow{8}{*}{$\begin{array}{l}\text { Social } \\
\text { loneliness }\end{array}$} & Constantly & 33 & 19.21 & 0.00 \\
\hline & Never & 14 & 76.23 & \\
\hline & Constantly & 33 & 18.02 & 0.02 \\
\hline & Very rarely & 25 & 72.43 & \\
\hline & Occasionally & 29 & 23.41 & 0.00 \\
\hline & Never & 14 & 72.53 & \\
\hline & Occasionally & 29 & 22.38 & 0.04 \\
\hline & Very rarely & 25 & 69.82 & \\
\hline \multirow{8}{*}{$\begin{array}{l}\text { Family } \\
\text { loneliness }\end{array}$} & Constantly & 33 & 14.23 & 0.00 \\
\hline & Never & 14 & 62.43 & \\
\hline & Constantly & 33 & 15.72 & 0.00 \\
\hline & Very rarely & 25 & 61.37 & \\
\hline & Occasionally & 29 & 19.34 & 0.04 \\
\hline & Never & 14 & 60.12 & \\
\hline & Occasionally & 29 & 20.12 & 0.02 \\
\hline & Very rarely & 25 & 59.23 & \\
\hline
\end{tabular}

It is evident from Table 5 that individual categories of subjects showed significant differences on the social loneliness $(p=0.00)$ and family loneliness $(p=0.01)$ subscales of the Social and Emotional Loneliness Scale for Adults with regard to the intensity of communication by using information technology (use of computers for video calls, social networks, etc.).
TABLE 5

KRUSKAL-WALLIS COMPARISON TEST OF SOCIAL AND FAMILY LONELINESS BY THE INTENSITY OF COMMUNICATION USING INFORMATION TECHNOLOGY

\begin{tabular}{lcc}
\hline Subscales & Chi-Square & $\mathrm{p}$ \\
\hline Social loneliness & 26.423 & 0.00 \\
Family loneliness & 41.586 & 0.01 \\
\hline
\end{tabular}

A post hoc Mann-Whitney Test Analysis was used to identify categories of intensity of communication through information technology. Table 6 shows only the results with a statistically significant difference between pairs within social loneliness and family loneliness subscales $(p \leq 0.05)$. Subjects who stated in the self-assessment that they "constantly" or "occasionally" communicated using information technology achieved statistically significantly lower results on the social loneliness subscale in comparison with the subjects stated that they "never" communicated. Similarly, subjects who claimed in the self-assessment questionnaire that they "constantly" or "occasionally" communicated using information technology achieved statistically significantly lower results on the family loneliness subscale when compared to the subjects who claimed that they "never" communicated. The obtained results demonstrated that respondents who stated in the self-assessment that they "constantly" or "occasionally" communicated using information technology during the COVID-19 pandemic showed lower levels of social and family loneliness on the Social and Emotional Loneliness Scale for Adults than the respondents who never communicated using information technology.

\section{TABLE 6}

MANN-WHITNEY TEST OF DIFFERENCES IN SOCIAL AND FAMILY LONELINESS BY COMMUNICATION INTENSITY WHEN USING INFORMATION TECHNOLOGY

\begin{tabular}{lcccc}
\hline Subscales & $\begin{array}{c}\text { Communication } \\
\text { intensity when } \\
\text { using informa- } \\
\text { tion technology }\end{array}$ & $\mathrm{N}$ & $\begin{array}{c}\text { mean } \\
\text { rank }\end{array}$ & $\mathrm{p}$ \\
\hline Social & Constantly & 18 & 17.32 & 0.00 \\
loneliness & Never & 42 & 71.21 & \\
& Occasionally & 30 & 22.45 & 0.00 \\
Family & Never & 42 & 71.01 & \\
loneliness & Constantly & 18 & 15.25 & 0.01 \\
& Never & 42 & 68.23 & \\
& Occasionally & 30 & 20,53 & 0.02 \\
& Never & 42 & 67.35 & \\
\hline
\end{tabular}

It is evident from Table 7 that there are significant differences between certain categories of respondents on the social loneliness $(p=0.03)$ and family loneliness 
$(p=0.04)$ subscales of the Social and Emotional Loneliness Scale for Adults with regard to communication intensity in face-to-face communication.

TABLE 7

KRUSKAL-WALLIS COMPARISON TEST OF SOCIAL AND FAMILY LONELINESS BY INTENSITY IN FACETO-FACE COMMUNICATION

\begin{tabular}{lcc}
\hline Subscales & Chi-Square & $\mathrm{p}$ \\
\hline Social loneliness & 28.357 & 0.03 \\
Family loneliness & 39.823 & 0.04 \\
\hline
\end{tabular}

A post hoc Mann-Whitney Test Analysis was used to identify communication intensity categories in face-to-face communication. Table 8 shows only the results with a statistically significant difference between pairs within subscales $(\mathrm{p} \leq 0.05)$. Subjects who stated in the self-assessment questionnaire that they "constantly" communicated face-toface achieved statistically significantly lower results on the social loneliness subscale when compared with the subjects who stated that they "never" communicated. Respondents who stated in the self-assessment that they "constantly" or "occasionally" communicated face-to-face achieved statistically significantly lower results on the family loneliness subscale in comparison with the respondents who stated that they "never" communicated. The obtained results demonstrate that subjects who wrote in the self-assessment that they "constantly" or "occasionally" communicated face-toface during the COVID-19 pandemic showed lower levels of family loneliness on the Social and Emotional Loneliness Scale for Adults when compared to the subjects who never communicated face-to-face. Similarly, respondents who wrote in the self-assessment that they occasionally communicated face-to-face showed a lower level of social loneliness on the Social and Emotional Loneliness Scale for Adults than the respondents who never communicated.

TABLICA 8

MANN-WHITNEY TEST OF DIFFERENCES IN SOCIAL AND FAMILY LONELINESS BY INTENSITY IN FACE-TOFACE COMMUNICATION

\begin{tabular}{lcccc}
\hline Subscales & $\begin{array}{c}\text { Communication } \\
\text { intensity in face-to-face } \\
\text { communication }\end{array}$ & $\mathrm{N}$ & $\begin{array}{c}\text { mean } \\
\text { rank }\end{array}$ & $\mathrm{p}$ \\
\hline Social & Occasionally & 41 & 18.54 & 0.00 \\
loneliness & Never & 7 & 79.56 & \\
Family & Constantly & 14 & 23.45 & 0.04 \\
loneliness & Never & 7 & 64.23 & \\
& Occasionally & 41 & 24.35 & 0.00 \\
& Never & 7 & 63.24 & \\
\hline
\end{tabular}

It is evident from Table 9 that there are significant differences between some categories of subjects on the social loneliness $(p=0.01)$ and family loneliness $(p=0.03)$ sub- scales of the Social and Emotional Loneliness Scale for Adults with regard to communication intensity when using mobile chat applications (Viber, Skype, WhatsApp, etc.).

TABLE 9

KRUSKAL-WALLIS COMPARISON TEST OF SOCIAL ND FAMILY LONELINESS BY COMMUNICATION INTENSITY WHEN USING MOBILE CHAT APPLICATIONS

\begin{tabular}{lcc}
\hline \multicolumn{1}{c}{ Subscales } & Chi-Square & $\mathrm{p}$ \\
\hline Social loneliness & 30.246 & 0.01 \\
Family loneliness & 41.758 & 0.03 \\
\hline
\end{tabular}

A post hoc Mann-Whitney Test Analysis was used to identify categories of intensity of communication when using mobile chat applications. Table 10 shows only the results with a statistically significant difference between pairs within subscales $(p \leq 0.05)$. Subjects who wrote in the self-assessment that they "constantly" or "occasionally" communicated using mobile chat applications achieved statistically significantly lower results on the social loneliness subscale when compared with the subjects who stated that they "never" communicated. Similarly, respondents who claimed in the self-assessment that they "constantly" or "occasionally" communicated using mobile chat applications achieved lower statistically significant results on the family loneliness subscale than the respondents who claimed that they "never" communicated. The obtained results demonstrate that subjects who stated in the self-assessments that they constantly or occasionally communicated using mobile chat applications during the COVID-19 pandemic showed lower levels of social loneliness and family loneliness on the Social and Emotional Loneliness Scale for Adults when compared to the subjects who never communicated using mobile chat applications.

TABLE 10

MANN-WHITNEY TEST OF DIFFERENCES IN SOCIAL AND FAMILY LONELINESS BY COMMUNICATION INTENSITY WHEN USING MOBILE CHAT APPLICATIONS

\begin{tabular}{lcccc}
\hline Subscales & $\begin{array}{c}\text { Communication intensity } \\
\text { when using mobile chat } \\
\text { applications }\end{array}$ & $\mathrm{N}$ & $\begin{array}{c}\text { mean } \\
\text { rank }\end{array}$ & $\mathrm{p}$ \\
\hline Social & Constantly & 23 & 18.98 & 0.03 \\
loneliness & Never & 43 & 69.54 & \\
& Occasionally & 26 & 25.41 & 0.02 \\
Family & Never & 43 & 70.26 & \\
loneliness & Constantly & 23 & 16.58 & 0.04 \\
& Never & 42 & 62.32 & \\
& Occasionally & 26 & 22.35 & 0.04 \\
& Never & 43 & 63.38 & \\
\hline
\end{tabular}




\section{Discussion}

Due to the current situation there is not much research into the use of various means of communication, especially information and communication technology, by the elderly during the COVID-19 pandemic or into potential benefits this activity could have. For this reason this research focused on getting a clearer insight (through selfassessment) into social and family loneliness of the elderly with regard to the communication methods used during the pandemic.

Since nonparametric procedures confirmed differences in self-assessment of social and family loneliness in older people during the COVID-19 pandemic with regard to the current level and type of communication intensity, we are presenting the following insights.

Differences in self-assessment of loneliness in the elderly during the COVID-19 pandemic with regard to the current level of communication were determined by the social loneliness and family loneliness subscales of the Social and Emotional Loneliness Scale for Adults. Subjects who stated in the self-assessment a higher level of communication intensity during the COVID-19 pandemic showed lower levels of social and family loneliness than the subjects who stated a lower level of communication. Differences in self-assessment of loneliness in the elderly during the COVID-19 pandemic with regard to the type of communication intensity (separately for each means of communication) were established by the social loneliness and family loneliness subscales of the Social and Emotional Loneliness Scale for Adults. Respondents who stated in the self-assessment questionnaire that they constantly or occasionally communicated by telephone/mobile phone, by face-to-face communication, by mobile chat applications (Viber, Skype, WhatsApp, etc.), or used information technology (computers for video calls, social networks, etc.) during the COVID-19 pandemic showed lower levels of social and family loneliness when compared to the respondents who never or very rarely communicated in the abovementioned ways.

Results of this research correspond to the other research which revealed that use of various means of communication, particularly information and communication technology, can strengthen a person's social network, which can be especially beneficial for the elderly whose social networks might decrease in time, 18,20,29,39-41. Older people who use information technology have better social resources and it is therefore not surprising that one of the most common reasons for using information technology is to keep in touch with family members and get social support ${ }^{18-20}$, since information technology mechanism reduces the feeling of social isolation and loneliness. Information technology can be helpful to the elderly because it enables them to maintain or improve their skills, connect and remain in contact with family members and friends, get information and news, and to be as independent and satisfied in life as possible regardless of their health status. Information technology, which in our case were various applications, social networks, etc., proved to be useful for older population since it became a tool which reduced their feeling of loneliness and social isolation during the COVID-19 pandemic.

\section{Conclusion}

Although use of information and communication technology by younger age groups is often associated with negative consequences, in an advanced age the Internet can become a suitable platform for communication and a way of gaining independence, particularly when older people are separated from their family members and friends or if they are less mobile. Wide availability of information technology can be helpful in reducing the feeling of loneliness in the elderly. Results of this research indicate that using various types of modern communication technologies had a positive effect on older people because they reduced the feeling of loneliness after the introduction of epidemiological measures of self-isolation and distancing to combat the COVID-19 pandemic, whereas the subjects with a lower level and intensity of communication showed higher levels of social and family loneliness. Nowadays in the world of highly developed technology, including information technology, there is a need to adapt information technology to suit the elderly and remove barriers preventing them to use information technology more often ${ }^{42}$. A multidisciplinary team of gerontologists, communication technologists and other experts should find a way for information technology to contribute to more satisfaction and improved quality of life of the elderly.

Finally, apart from transverse sampling another limitation in this research was the use of self-assessment, particularly single constructs. However, according to some authors ${ }^{43}$, when compared to scales or questionnaires single constructs can be suitable if well operationalized, which we believe was the case in this research. Other limitations were related to the relatively small sample which limited the range of possible analyses and weight of the applied tests. A suggestion for further research would be to confirm the significance of the obtained results on a larger sample in similar or rural areas. Future research should be multidisciplinary and preferably longitudinal in which older people would be monitored in multiple measuring points to determine potential benefits of the use of information technology in successful aging. It would be particularly interesting and useful to monitor elderly subjects before and after learning to use information technology.

This work presents a positive example of using information and communication technology during the COVID-19 pandemic. There are many other positive examples which remain to be proved. Despite the limitations in this research (which could become guidelines for future research), we consider this research the first step in explaining the importance of using information technology in old age. We expect this topic to attract interest of researchers across different fields, since current trends and global projects in developed countries show that information technology and aging have become indispensable topics of practical value for multidisciplinary research. 


\section{R E F E R E N C E S}

1. GUO YR, CAO QD, HONG ZS, TAN YY, CHEN SD, JIN HJ, TAN KS, WANG DY, YAN Y, Military Medical Research, 7 (2020) 11. doi: https:// doi.org/10.1186/s40779-020-00240-0. — 2. SMITH K, Social Isolation Is Linked to Higher Levels of Inflammation, Studies Show, accessed 12.05.2020. Available from: https://www.sciencealert.com/social-isolationlinked-to-higher-levels-of-inflammation-says-new-study. - 3. PERLMAN D, PEPLAU LA, Loneliness research: A survey of empirical findings. In: PEPLAU LA, GOLDSTON S (Eds.) Preventing the harmful consequences of severe and persistent loneliness (US Government Printing Office, Rockville, 1984). - 4. WENGER GC, DAVIES R, SHAHTAHMASEBI S, SCOTT A, Ageing and Society, 16 (1996) 333. DOI: 10.1017/ S0144686X00003457. - 5. VALTORTA N, HANRATTY B, Journal of the Royal Society of Medicine, 105 (2012) 518. DOI:10.1258/jrsm.2012.120128. - 6. FAKOYA OA, MCCORRY NK, DONNELLY M, BMC Public Health, 20 (2020) 129. doi: 10.1186/s12889-020-8251-6. - 7. VULETIĆ G, STAPIĆ M, Klinička psihologija 6 (2013) 45. - 8. KILLAM K, How to Prevent Loneliness in a Time of Social Distancing, accessed 12.05.2020. Available from: https://www.scientificamerican.com/article/how-to-prevent-loneliness-in-a-time-of-social-distancing/. - 9. BRAJKOVIĆ L, Pokazatelji zadovoljstva životom u trećoj životnoj dobi. PhD Thesis. In Croat (University of Zagreb, Zagreb, 2010). - 10. ZAHAVA G, BOWLING A, Ageing and Society, 24 (2004) 675. doi: https://doi.org/10.1017/S0144686X03001582. — 11. PRICE CA, BALASWAMY S, The International Journal of Aging and Human Development, 68 (2009) 195. DOI: 10.2190/AG.68.3.b. - 12. CICAK M, Ljetopis socijalnog rada, 17 (2009)109. - 13. GIERVELD JJ, Clinical Gerontology, 8 (1998) 73. - 14. LACKOVIĆ-GRGIN K, Usamljenost-fenomenologija, teorije i istraživanja. (Naklada Slap, Jastrebarsko, 2008). - 15. DRŽAVNI ZAVOD ZA STATISTIKU, Popis stanovništva, kućanstva i stanova 2011, accessed 04.05.2020. Available from: www.dzs. hr/Hrv_Eng/publication/2012/SI-1468.pdf. - 16. EUROSTAT, Digital economy and society statistics - households and individuals, accessed 06.06.2020. Available from: http:// ec.europa.eu/eurostat/statistics-explained/index.php/Digital_economy_and_society_statistics_-_households_ and_individuals. - 17. XAVIER AJ, D'ORSI E, DE OLIVEIRA CE, ORRELL M, DEMAKAKOS P, BIDDULPH JP, MARMOT MG, Journals of Gerontology: Medical Sciences, 69 (2014) 1117. doi: https://doi.org/10.1093/ gerona/glu105. - 18. HOGEBOOM DL, McDERMOTT RJ, PERRIN KM, OSMAN H, BELL-ELLISON BA, Educational Gerontology, 36 (2010) 93. doi: 10.1080/03601270903058507. — 19. CHOPIK WJ, Cyberpsychology, Behavior and Social Networking, 19 (2016) 551. doi: 10.1089/cyber.2016.0151. - 20. GARBIN PRANIČEVIĆ D, PETERLIN J, BUĆAN JM, Dubrovnik International Economic Meeting, 3 (2017) 145. — 21. ALMEIDA OP, YEAP BB, ALFONSO H, HANKEY GJ, FLICKER L, NORMAN PE, PLoS One, 7 (2012) e44239. doi: 10.1371/ 0044239. - 22. ORDONEZ TN, YASSUDA MS, CACHIONI M, Archives of Gerontology and Geriatrics, 53 (2011) 216. doi: 10.1016/j.archger.2010.11.007. - 23. CAS-
TILLA D, BOTELLA C, MIRALLES I, BRETÓN-LÓPEZ J, DRAGOMIRDAVIS AM, ZARAGOZA I, GARCIA-PALACIOS A, International Journal of Human-Computer Studies, 118 (2018) 24. doi: 10.1016/j.ijhcs.2018.05.009. -24. CANGELOSI PR, SORRELL JM, Journal of Psychosocial Nursing and Mental Health Services, 52 (2014) 17. doi: https://doi. org/10.3928/02793695-20140721-01. - 25. ANDREWS JA, BROWN LJE, HAWLEY MS, ASTELL AJ, Journal Of Medical Internet Research, 21 (2019) e11694. doi: 10.2196/11694. - 26. GIACOMO DD, RANIERI J, D'AMICO M, GUERRA F, PASSAFIUME D. Behavioral Sciences, 9 (2019) 96. doi: 10.3390/bs9090096. - 27. BEKALU MA, MCCLOUD RF, VISWANATH K, Health Educ Behav, 46 (2019) 69. doi: 10.1177/1090198119863768. - 28. COTTEN SR, FORD G, FORD S, HALE TM, Journal of Gerontology: Series B, 69 (2014) 763. doi: 10.1093/geronb/gbu018. - 29. HAYDAR SA, GAMZE GY, GÜLŞAH T, NALAN K, Procedia - Social and Behavioral Sciences, 55 (2012) 1053. doi: 10.1016/j.sbspro.2012.09.597. - 30. BRESLAU J, AHARONI E, PEDERSEN ER, MILLER LL, A Review of Research on Problematic Internet Use and Well-Being (RAND Corporation, Santa Monica, 2015). - 31. STOŽER CIVILNE ZAŠTITE REPUBLIKE HRVATSKE, Odluke Stožera civilne zaštite za sprječavanje širenja zaraze novim koronavirusom. Available from: https://www.koronavirus.hr/ zadnje-azurirano/57. - 32. ĆUBELA ADORIĆ V, NEKIĆ M, Skala socijalne i emocionalne usamljenosti. In: Proroković A (Ed) Zbirka psihologijskih skala i upitnika (Sveučilište u Zadru, Filozofski fakultet, Zadar 2004). - 33. DITOMASSO E, SPINNER B, Personality and Individual Differences, 14 (1993) 127. doi: 10.1016/0191-8869(93)90182-3. — 34. NAKAMURA E, MIYAO K, The Journals of Gerontology: Series A, 63 (2008) 936. doi: 10.1093/gerona/63.9.936. - 35. KIM LH, Journal of Preventive Medicine and Public Health, 44 (2011) 32. doi: 10.3961/jpmph.2011.44.1.32. - 36. JAGGER C, Trends in life expectancy and healthy life expectancy. Available from: https://assets.publishing.service.gov.uk/government/uploads/system/uploads/attachment_data/file/464275/gs-15-13-future-ageing-trends-life-expectancy-er12.pdf. - 37. MCGRATH R, AL SNIH S, MARKIDES K, HALL O, PETERSON M, BMC Geriatrics, 19 (2019) 1. doi: 10.1186/s12877-019-1110-6. - 38. UNITED NATIONS, World population prospects: the 2019 revision. Available from: https:// population.un.org/ wpp/.- 39. HAVENS B, HALL M, SYLVESTRE G, JIVAN T, Canadian Journal on Aging, 23 (2004) 129. doi: 10.1353/cja.2004.0022. - 40. ROKACH A, ORZECK T, NETO F, Current Psychology, 23 (2004) 124. DOI: 10.1007/BF02903073. - 41. BOASE J, HORRIGAN JB, WELLMAN B, RAINIE L, The strength of internet ties, Pew Internet \& American Life Project. Available from: https://www.pewresearch.org/internet/2006/01/25/ the-strength-of-internet-ties/._42. TELEBUH M, BERTIĆ Ž, ZNIKA M, POLJAK D, Media, culture and public relations, 7 (2016) 200. - 43. GARDNER DG, CUMMINGS LL, DUNHAM RB, PIERCE JL, Educational and Psychological Measurement, 58 (1998) 898. doi: 10.1177/0013164498058006003.

\section{Ž. Bertić}

Institute of Public Health of Bjelovar-Bilogora County, Matice hrvatske 15, 43000 Bjelovar, Croatia e-mail: bertic.z@gmail.com 
RAZLIKA U SAMOPROCJENI SOCIJALNE I OBITELJSKE USAMLJENOSTI KOD STARIJIH OSOBA TIJEKOM PANDEMIJE COVID-19 U ODNOSU NA AKTUALNU RAZINU I VRSTU INTENZITETA KOMUNIKACIJE

\section{S A Ž E T A K}

Zbog širenja korona virusa ljudi diljem svijeta pa tako i u Hrvatskoj prisiljeni su na socijalno distanciranje čime raste broj osoba koje ulaze u rizik još jednog javnozdravstvenog problema, a to je usamljenost. Usamljenost se može definirati kao stanje prisutnosti negativnih osjećaja povezanih s percipiranom socijalnom izolacijom, te se navodi kao jedan od najizraženijih problema starenja. Relativno je malen broj istraživanja koja se bave korištenjem različitih metoda komuniciranja, posebice informacijsko komunikacijskih tehnologija kod starijih osoba tijekom pandemije COVID-19 i utvrđivanja eventualne dobiti koja bi ta aktivnost imala. Cilj ovog istraživanja bio je utvrditi razliku u samoprocjeni socijalne i obiteljske usamljenosti prema načinu komunikacije kod starijih osoba tijekom pandemije COVID-19. Istraživanje je provedeno u ožujku i travnju 2020. godine, točnije u periodu od uvođenja epidemioloških mjera socijalnog distanciranja i samoizolacije do perioda popuštanja mjera u suzbijanju širenja korona virusa u Hrvatskoj. U istraživanju je sudjelovalo 107 ispitanika starosti višoj od 65 godina koji žive u vlastitom kućanstvu na području Bjelovara. Za potrebe istraživanja je konstruiran Indeks o učestalosti načina komunikacije. Za provjeru razine usamljenosti korištena je Skala socijalne i emocionalne usamljenosti. Dobiveni rezultati ukazuju da manju socijalnu i obiteljsku usamljenost pokazuju ispitanici koji samoprocjenjuju višu razinu komunikacije tijekom pandemije COVID-19 putem razgovara telefonom/mobitelom, informacijskom tehnologijom (uporabom računala: video poziv, socijalne mreže i dr.), razgovora lice u lice te putem mobilnih aplikacija (Viber, Skype, WhatsApp i dr.). Ispitanici koji uopće ne komuniciraju i oni koji vrlo rijetko komuniciraju bilo kojim od ispitivanih načina komunikacije pokazali su veću socijalnu i obiteljsku usamljenost. Rezultati ovoga istraživanja ukazuju na pozitivan primjer korištenja različitih metoda komuniciranja, posebice modernih tehnologija za komunikaciju kod starijih osoba u smanjenju usamljenosti. Kroz timski rad gerontologa, komunikacijskih tehnologa i ostalih stručnjaka koji se bave starijim osobama komunikacijska tehnologija mogla bi se približiti starijim osobama i doprinijeti zadovoljnijem i kvalitetnijem životu osoba starije životne dobi. 
